\title{
ANALISIS PEMBELAJARAN DAN PENCAPAIAN PERKEMBANGAN ANAK USIA DINI PADA MASA PANDEMI COVID-19 DI LEMBAGA PAUD KOTA METRO LAMPUNG
}

\author{
Maya Arbasari ${ }^{1}$, Marzuki Noor ${ }^{2}$, Agus Sutanto ${ }^{3}$ \\ ${ }^{1}$ Yayasan Pendidikan Komariyah Diniah Islamiah ${ }^{, 2,3}$ Universitas MuhammmadiyahMetro \\ E-mail: $\quad$ aya.arbas@gmail.com $\left.{ }^{1}\right)$ \\ marzuki4metro@gmail.com ${ }^{2}$ ) \\ sutanto11@gmail.com ${ }^{3}$ )
}

\begin{abstract}
Abstrak
Pandemi Covid-19 yang terjadi di seluruh belahan dunia berdampak serius, pendidikan di semua jenjang telah berhenti belajar tatap muka dan beralih ke sistem pembelajaran online. Akibatnya, perubahan metode pembelajaran yang sangat mendadak, menimbulkan perubahan sistem pembelajaran. Pembelajaran PAUD bersifat holistik dan terpadu, yang mengembangkan semua aspek. Pembelajaran bersifat terpadu dan tidak mengajarkan bidang studi secara terpisah sehingga satu kegiatan dapat menjadi wahana belajar berbagai hal bagi anak. Untuk itu diperlukan upaya guru yang efektif untuk meningkatkan pembelajaran pada masa pandemi Covid-19. Tujuan penelitian untuk mengidentifikasi proses pembelajaran PAUD, mengidentifikasi pencapaian perkembangan anak, dan mendeskripsikan upaya guru untuk meningkatkan pembelajaran pada masa pandemi Covid-19. Desain yang digunakan dalam penelitian ini yaitu penelitian kualitatif deskriptif. Penelitian ini dilakukan di Lembaga PAUD TK Cahaya Bangsa dan TK Aisyiyah Iringmulyo pada masa Pandemi Covid-19 Tahun Pelajaran 2020 - 2021. Metode pengumpulan data menggunakan teknik wawancara, observasi, angket dan studi dokumentasi. Hasil penelitian ini adalah pembelajaran untuk masa pademi Covid-19 membuat Kurikulum khusus. Pemilihan metode pembelajaran yang digunakan oleh guru adalah menggunakan metode luring dan daring. Materi pembelajaran yang di pilih oleh guru adalah memberikan peserta didik materi yang tidak memberatkan orangtua dan menyesuaikan lingkungan rumah tinggal dimana alat dan bahan mudah diperoleh. Aplikasi yang digunakan guru PAUD di Kota Metro dalam menyampaikan pembelajaran menggunakan media Whatsapp group (WA), zoom meeting, quizizz dan simple paint. Upaya guru dalam meningkatkan ketercapaian perkembangan anak meliputi enam aspek perkembangan.
\end{abstract}

Kata kunci: Pembelajaran PAUD, Pencapaian Perkembangan anak; Pandemi Covid-19

\begin{abstract}
The Covid-19 pandemic that occurred in all parts of the world had a serious impact, education at all levels had stopped face-to-face learning and switched to an online learning system. As a result, changes in learning methods are very sudden, causing changes in the learning system. PAUD learning is holistic and integrated, which develops all aspects. Learning is integrated and does not teach fields of study separately so that one activity can be a vehicle for learning various things for children. For this reason, effective teacher efforts are needed to improve learning during the Covid-19 pandemic. The research objectives were to identify the PAUD learning process, identify the achievement of children's development, and describe the efforts of teachers to improve learning during the Covid-19 pandemic. The design used in this research is descriptive qualitative research. This research was conducted at the PAUD Institute TK Cahaya Bangsa and TK Aisyiyah Iringmulyo during the Covid-19 Pandemic in the 2020-2021 Academic Year. The data collection methods used interview, observation, questionnaire and documentation studies techniques. The results of this study are learning for the Covid-19 pandemic to create a special curriculum. The selection of learning methods used by teachers is using offline and online methods. The learning material chosen by the teacher is to provide students with material that does not burden parents and adapts to the residential environment where tools and materials are easily obtained. Applications used by PAUD teachers in Metro City in delivering learning using Whatsapp group (WA) media, zoom meetings, quizzz and simple paint. The teacher's efforts in increasing the achievement of children's development include six aspects of development.
\end{abstract}

Keywords: PAUD learning, child development 


\section{PENDAHULUAN}

Pada 31 Januari 2020, Organisasi Kesehatan Dunia (WHO) menyatakan Covid-19 sebagai darurat kesehatan manusia dan masalah internasional yang berisiko tinggi. Kemudian, WHO mengumumkan pada 11 Maret 2020 bahwa Covid-19 telah menjadi pandemi. Mengingat virus Covid-19 menyebar begitu cepat, dan belum ada vaksin yang ditemukan saat itu, maka satu-satunya upaya untuk mencegah penyebaran virus tersebut lebih luas dan satu-satunya upaya dengan jumlah pasien yang lebih sedikit adalah tindakan pencegahan yang efektif, yaitu dengan menjaga jarak fisik (physical distancing) dan menjaga jarak sosial (social distancing). Pandemi Covid-19 yang terjadi di hampir seluruh belahan dunia berdampak serius, termasuk di Indonesia, di mana pendidikan di semua jenjang telah berhenti belajar tatap muka dan beralih ke sistem pembelajaran online atau jarak jauh (Kemdikbud) dan Kebudayaan Republik Indonesia, 2020). Akibatnya, dengan perubahan metode pembelajaran yang sangat mendadak yang tidak sedikit menimbulkan kekagetan budaya bagi guru dan anak didik. Salah satu penyebab terjadinya kekagetan budaya dapat mengganggu sistem regulasi dalam pembelajaran, tergangunya motivasi berprestasi dan interaksi pembelajaran yang kurang memuaskan.

Pembelajaran PAUD bersifat holistik dan terpadu, yang mengembangkan semua aspek, yaitu aspek nilai agama dan moral, fisik motorik, kognitif, bahasa, sosial emosional dan seni. Pembelajaran bersifat terpadu dan tidak mengajarkan bidang studi secara terpisah sehingga satu kegiatan dapat menjadi wahana belajar berbagai hal bagi anak. Kegiatan pembelajaran anak usia dini di PAUD yang berkualitas akan sulit tercapai sebab pembelajaran di PAUD menuntut guru untuk lebih dekat baik secara psikologis juga secara fisik, pembelajaran untuk anak usia dini lebih bersifat non formal, dilakukan melalui kegiatan dengan banyak aktivitas bermain dan tidak memiliki capaian prestasi yang bersifat akademik akan tetapi optimalisasi perkembangan anak, sehingga guru dapat menciptakan suasana pembelajaran yang nyaman dan aman bagi anak. Hal ini tidak dapat terbantahkan bahwa peran guru PAUD dalam pembelajaran memegang posisi yang sangat penting, strategis dan bahkan menjadi kunci untuk mencapai pembelajaran yang bermutu dan efektif.

Beberapa hal yang berbeda dalam belajar mengajar sebelum dan selama pandemi di sekolah PAUD. Sebelum terjadinya Covid-19, sekolah melakukan tatap muka, guru dapat dengan leluasa memberikan pembelajaran yang dilakukan dengan melibatkan dan memanfaatkan lingkungan sekitar sekolah, guru mampu melakukan stimulasi dan pengamatan secara langsung terhadap pencapaian perkembangan anak didik (aspek nilai agama dan moral, fisik motorik, kognitif, bahasa, sosial emosional, dan seni) setiap hari, memberikan dukungan dan rangsangan langsung kepada anak didik. Namun selama pandemi Covid-19 guru tidak dapat melakukan pembelajaran dengan tatap muka, tidak dapat berinteraksi langsung dengan anak didik, program dan target belajar serta pembiasaan karakter tidak terpantau secara langsung oleh guru untuk memperoleh gambaran tentang kesulitan Guru secara micro diatas, peneliti melakukan pra survei. Berdasarkan hasil wawancara dan diskusi pada tanggal 27 Oktober 2020 sampai dengan tanggal 31 Oktober 2020 bersama 20 lembaga PAUD, 20 responden guru melalui diskusi via group whatsapp menjelaskan bahwa pada masa pandemi Covid-19, guruguru PAUD di Kota Metro ternyata masih mengalami beberapa kesulitan atau kebingungan menentukan metode pembelajaran, kebingungan membuat materi rencana pembelajaran, dan kebingungan dalam memilih fasilitas teknologi informasi dan komunikasi atau media pembelajaran yang akan digunakan untuk proses belajar dari rumah.

Tabel 1. Data Pra Survei kesulitan guru - guru PAUD di Kota Metro 
pada Masa Pandemi Covid- 19

\begin{tabular}{clcc}
\hline No & \multicolumn{1}{c}{ Kesulitan } & Sulit & Mudah \\
\hline 1. & Metode pembelajaran & $65 \%$ & $35 \%$ \\
\hline 2. & Materi pembelajaran & $65 \%$ & $35 \%$ \\
\hline 3. & Penggunaan Teknologi & $60 \%$ & $40 \%$ \\
\hline & Jumlah presentasi & $63,3 \%$ & $36,7 \%$ \\
\hline
\end{tabular}

Sumber : data dokumentasi hasil wawancara Guru PAUD Kota Metro

Dari data pra survei tentang kesulitan yang dialami Guru PAUD di Kota Metro dilihat masih banyak guru yang mengalami kesulitan dalam menentukan metode, materi pembelajaran dan penggunaan teknologi untuk proses pencapaian perkembangan peserta didiknya.

Kesulitan metode pembelajaran, $65 \%$ Guru PAUD di Kota Metro mengalami kebingungan menentukan metode mengajar yang tepat pada masa pandemi Covid-19. Karena pembelajaran di sekolah di hentikan dan digantikan degan pembelajaran jarak jauh atau belajar dari rumah, maka guru mengalami kebingungan menggunakan metode pembelajaran apa yang tepat untuk peserta didiknya. Metode pembelajaran dalam kegiatan belajar anak usia dini memegang peranan yang sangat penting. Seorang guru di PAUD harus mampu dan paham dalam menerapkan metode pembelajaran yang bervariasi sehingga guru dapat merancang pembelajaran yang menarik, menyenangkan, dan bermakna. Hal tersebut diharapkan agar peserta didik dapat memahami pembelajaran yang dilakukannya lebih baik dan berbekas lama diri anak didik.

Kesulitan guru dalam membuat materi pembelajaran yang menarik untuk peserta didiknya. 65\% guru memberikan jawaban bahwa pada saat pandemi covid-19 sebagian besar mengalami kesulitan dalam hal membuat materi rencana pembelajaran yang tepat dan mendeskripsikan penilaian perkembangan anak. Kegiatan perencanaan pembelajaran tentunya bagian yang sangat penting dalam kegiatan pembelajaran anak usia dini. Apalagi kegiatan pembelajaran di PAUD bersifat tematik dan terintegratif sehingga dituntut kejelian, keseriusan dan juga kreativitas guru dalam melakukannya. Meskipun Menteri Pendidikan dan Kebudayaan (Mendikbud) Nadiem Anwar Makarim menerbitkan Surat Edaran Nomor 4 Tahun 2020 tentang Pelaksanaan Pendidikan Dalam Masa Darurat Coronavirus Disease (Covid-19). Salah satu pokok penting adalah terkait belajar dari rumah. Adapun aktivitas dan tugas pembelajaran dapat bervariasi antar anak didik, sesuai minat dan kondisi masing-masing, termasuk dalam hal kesenjangan akses/fasilitas belajar di rumah. Guru masih mengalami kesulitan dalam menentukan materi belajar yang tepat.

Kesulitan menggunakan fasilitas media teknologi informasi dan komunikasi yang tersedia baik guru maupun oragtua peserta didik. $60 \%$ hasil wawancara menceritakan bahwa hal ini merupakan tantangan baru baik bagi guru PAUD maupun bagi orang tua anak didik agar proses pendidikan tetap berjalan sesuai dengan kurikulum dan tujuan dari pendidikan. Dalam pelaksanaannya, belajar dari rumah tidaklah mudah. Faktor kurangnya semangat anak dan kurangnya kemampuan orang tua dalam mendampingi anak menjadi tantangan dalam penerapan metode pembiasaan.

Oleh karena itu, dipandang perlu untuk mencari solusi yang tepat untuk Guru dalam menangani permasalah kesulitan pembelajaran pada masa pandemi Covid-19, betapa pentingnya pemilihan metode, materi rencana pembelajaran dan penggunaan media teknologi informasi dan komunkasi untuk pembelajaran yang sesuai dengan anak usia dini yang perlu dipahami oleh berbagai pihak terutama guru dan orangtua peserta didik, agar dapat memberikan pelayanan 
yang optimal dalam mengembangkan pribadi anak usia dini secara tepat. Hal ini penting, agar implementasi pembelajaran betul-betul dapat berfungsi membina dan menumbuh kembangkan seluruh potensi anak secara optimal, serta agar terbentuk perilaku dan kemampuan dasar yang selaras, serasi dan seimbang dengan tahap perkembangannya, sehingga memiliki kesiapan untuk memasuki pendidikan selanjutnya dalam mewujudkan tujuan pendidikan yang lebih luas lagi. Sejatinya tujuan pendidikan yaitu secara kaffah, bukan hanya sukses menghadapi kehidupan di dunia saja, tetapi juga siap menghadapi kehidupan di akhirat.

Wabah global terjadi di Indonesia, Virus Corona juga mewabah di Indonesia sejak awal Maret hingga saat ini 12 Mei 2020 terdapat 17.514 positif terkonfimasi tersebar di 34 provinsi dan 415 kabupaten/kota (Gugus Tugas Percepatan Penanganan Covid-19 Indonesia, update 12/5/2020).

Rohayani (2020:30) menarik kesimpulan kebahagiaan anak menjadi faktor utama baiknya perkembangan anak, baik itu ketika berada di dalam rumah maupun di luar rumah. Oleh karena itu, orang tua harus bisa menciptakan lingkungan yang aman, nyaman, harmonis dan kasih sayang dalam keluarga untuk mempererat emosional orang tua dengan anak, terlebih lagi selama masa Pandemi Covid-19 yang mengharuskan anak dan orang tua harus terus menerus berada di rumah.

Achmad (2020:67) "menyimpulkan pandemic Covid-19 secara tiba-tiba mengharuskan elemen pendidikan untuk mempertahankan pembelajaran secara online. Kondisi saat ini mendesak untuk melakukan inovasi dan adaptasi terkait pemanfaatan teknologi yang tersedia untuk mendukung proses pembelajaran".

Gunawan (2020:67) "Guru harus maupun berinteraksi dengan anak didik dan melakukan transfer pengetahuan secara online. Pembelajaran online dapat memanfaatkan platform berupa aplikasi, website, jejaring social maupun learning management system".

Berdasarkan pendapat diatas dapat disimpulkan Pandemi Covid-19 membawa dampak perubahan di segala bidang, bukan hanya berdampak pada bidang ekonomi, kesehatan dan keamanan, namun juga bidang pendidikan. Seluruh jenjang pendidikan di Indonesia mengalami perubahan metode dalam pembelajaran. Sekolah - sekolah menghentikan aktivitas pendidikan secara tatap muka serta berubah dengan sistem daring, belajar jarak jauh atau belajar dari rumah. Adanya wabah Pandemi Covid-19 menjadikan kendala karena metode pembelajaran yang sudah dilakukan selama ini berbeda dengan sebelumnya.

\section{Pembelajaran PAUD}

Dalam Peraturan Menteri Pendidikan dan Kebudayaan RI No. 137 Tahun 2014 tentang Standar Nasional PAUD mengemukakan bahwa "Pembelajaran adalah proses interaksi antar anak didik, antara anak didik dan pendidik dengan melibatkan orangtua serta sumber belajar pada suasana belajar dan bermain di satuan PAUD".

Wiyani dan Barnawi (2012:88) menerangkan bahwa "pembelajaran yang berorientasi pada anak usia dini yang disesuaikan dengan tingkat usia anak, artinya pembelajaran harus diminati, kemampuan yang diharapkan dapat dicapai, serta kegiatan belajar dapat menantang peserta didik untuk dilakukan sesuai usia anak".

Komalasari, (2010:3) menyimpulkan "pembelajaran merupakan suatu proses yang dirancang, dilakukan, dan dievaluasi untuk siswa secara runtut dengan efektif dan efisien agar mendapatkan hasil sesuai tujuan yang diharapkan".

Dari pendapat di atas dapat di simpulkan bahwa pembelajaran adalah proses interaksi antara anak didik, pendidik dengan melibatkan orangtua serta sumber belajar pada suasana 
belajar dan bermain agar mencapai tujuan yang diharapkan. Usaha seorang Guru untuk membelajarkan anak didiknya berorientasi pada pencapaian perkembangan kompetensi anak usia dini yang disesuaikan dengan tingkat usia anak. Guru menyiapkan rencana materi pembelajaran dan proses belajar anak.

\section{a. Karakteristik Pembelajaran PAUD}

Karakeristik merupakan bagian dari kepribadian. Menurut kamus besar Bahasa Indonesia karakteristik memiliki persamaan kata karakter atau watak yang berarti sifat batin yang mempengaruhi segenap pikiran, prilaku, budi pekerti, dan tabiat yang dimiliki manusia atau makhluk hidup lainnya. Arti lain dari karakter yaitu konsekuen tindaknya dalam mematuhi etika perilaku, konsisten tindaknya dalam memegang pendirian atau pendapat.

Peraturan Menteri Pendidikan dan Kebudayaan RI No 146 tahun 2014 tentang Kurikulum 2013 PAUD, karakteristik kurikulum PAUD sebagai berikut: 1) Mengoptimalkan perkembangan anak yang meliputi : aspek nilai agama dan moral, fisik motorik, kognitif, bahasa, sosial emosional dan seni yang tercermin dalam keseimbangan kompetensi sikap, pengetahuan dan keterampilan, 2) Menggunakan pembelajaran tematik dengan pendekatan saintifik dalam pemberian rangsangan pendidikan, 3) Menggunakan penelitian autentik dalam memantau perkembangan anak, 4) Memberdayakan peran orangtua dalam proses pembelajaran

\section{b. Komponen Pembelajaran PAUD}

Pembelajaran di PAUD terdapat komponen yang saling terkait satu sama lain. Apabila ada salah satu komponen pembelajaran tidak diterapkan maka proses pembelajaran berlangsung dengan kurang efektif. Keseluruhan dari komponen yang saling berinteraksi antara satu sama lain untuk mencapai tujuan pembelajaran yang telah ditetapkan oleh guru sebelumnya sebagai suatu upaya yang dilakukan oleh guru agar anak didik di rumah dapat melaksanakan proses belajar bersama orangtua.

Hamalik (2006:77) menarik kesimpulan ada tujuh aspek dalam komponen pembelajaran, yaitu: (1) tujuan dalam pembelajaran, (2) siswa/peserta didik (3) Guru/pendidik, (4) perencanaan pengajaran sebagai suatu segmen kurikulum, (5) strategi pembelajaran, (6) media pembelajaran, dan (7) penilaian pembelajaran. Kegiatan pembelajaran ditandai dengan interaksi dari komponen-komponen yang ada yaitu guru/pendidik, siswa, model dan metode pembelajaran, media pembelajaran, dan lingkungan belajar".

Mutiah (2010:120) komponen sistem pembelajaran meliputi tujuan, materi pembelajaran, metode atau strategi pembelajaran, media, dan evaluasi.

Berdasarkan beberapa pendapat ahli di atas, dikatakan terdapat beberapa komponen penting yang harus ada pada pembelajaran, agar pembelajaran dapat terlaksana, antara lain : anak didik/peserta didik, guru, tujuan, materi, metode, media/alat pembelajaran, serta evaluasi pembelajaran. Setiap komponen ini saling berhubungan.

\section{c. Prinsip Pembelajaran PAUD}

Pendidikan anak usia dini sangat penting dalam masa pertumbuhan dan perkembangan setiap anak dalam tingkat dasarnya, sehingga, anak dapat mempersiapkan diri dalam memasuki jenjang pendidikan yang selanjutnya.

Prinsip-prinsip pembelajaran PAUD yang tertuang dalam Peratuan Menteri Pendidikan dan Kebudayaan RI No. 146 Tahun 2014 digunakan dalam proses pembelajaran antara lain :

1) Belajar melalui bermain, 2) Berorientasi pada perkembangan anak, 3) Berorientasi ada kebutuhan, 4) Berpusat pada anak, 5) Pembelajaran aktif, 6) Berorientasi pada pengembangan nilai-nilai karakter, 7) Berorientasi pada pengembangan kecakapan hidup, 8) Didukung oleh 
lingkungan yang kondusif, 9) Berorientasi pada pembelajaran yang demokratis, 10) Pemanfataan media belajar, sumber belajar dan narsaumber.

Pelaksanaan dalam kondisi khusus dimaksud untuk memberikan fleksibelitas bagi satuan pendidikan untuk menentukan kurikulum yang sesuai dengan kebutuhan pembelajaran peserta didik. Ada tiga opsi yang dapat dipilih yaitu : 1) Satuan pendidikan tetap mengacu pada Kurikulum Nasional 2013 PAUD, 2) Menggunakan kurikulum darurat, 3) Melakukan penyederhanaan kurikulum secara mandiri.

Berdasarkan beberapa peraturan pemerintah tentang pelaksanaan kurikulum PAUD, pemilihan dalam pelaksanaan dan penerapan kurikulum pembelajaran harus tetap memperhatikan usia dan tahapan perkembangan anak dan prinsip-prinsip pembelajaran PAUD, yaitu bermain dan belajar serta kebermaknaannya yaitu pembelajaran bagi pertumbuhan dan perkembangan anak.

\section{Pencapaian Perkembangan Anak}

Pencapaian perkembangan menggambarkan pertumbuhan dan perkembangan yang diharapkan dicapai anak pada rentang usia tertentu. Perkembangan anak usia dini adalah perubahan-perubahan yang dialami oleh individu menuju tingkat kedewasaannya, pertumbuhan dan perkembangan anak yang dapat dicapai pada rentang usia tertentu yang berintegrasi dengan enam aspek perkembangan :

\section{a. Aspek Perkembangan Nilai Agama dan Moral}

Perkembangan moral seorang anak sangat dipengaruhi oleh lingkungannya, terutama dari orangtuanya. Anak belajar untuk mengenal nilai-nilai dan berprilaku sesuai dengan nilai nilai tersebut.

Khaironi (2018:3) menarik kesimpulan "Moral dan agama merupakan sesuatu yang abstrak. Keduanya akan terlihat oleh indera penglihatan apabila ditunjukkan melalui perilaku dalam kehidupan sehari-hari. Seseorang akan dikatakan memiliki ketaatan terhadap agamanya jika melaksanakannya dalam berbagai kegiatan ibadah sesuai dengan ajaran agamanya. Begitu juga dengan moral, seseorang akan dikatakan memiliki moral yang baik jika berperilaku (menunjukkan perilaku) sesuai dengan aturan atau mengikuti aturan-aturan yang ada di dalam kelompoknya".

Wulandari dan Purwanta (2020:456) menarik kesimpulan pencapaian perkembangan nilai agama dan moral sebagai "Perkembangan nilai agama dan moral yang baik akan mendorong anak membiasakan bersikap dan berperilaku sesuai dengan nilai agama dan moral yang di anut anak, sehingga anak-anak dapat hidup dengan baik sesuai dengan nilai-nilai yang dijunjung oleh masyarakat dan juga dapat membantu mereka mengembangkan berbagai keterampilan hidup. Selain itu, pencapaian perkembangan nilai-nilai agama dan moral baik sejak dini juga merupakan salah satu cara untuk membangun karakter yang baik pada anak, karena karakter yang baik sangat dibutuhkan dalam pengembangan generasi masa depan bangsa".

Berdasarkan pendapat di atas, aspek perkembangan nilai agama dan moral merupakan sesuatu yang abstrak, yang terlihat oleh indera penglihatan apabila ditunjukkan melalui perilaku dalam kehidupan sehari-hari. Pencapaian perkembangan nilai-nilai agama dan moral merupakan salah satu cara untuk membangun karakter yang baik pada anak yang perlu diperhatikan guru dalam memberikan pembelajaran kepada anak didiknya antara lain dengan menstimulasi kemampuan anak untuk mempraktikan berbagai pengalaman keagamaan dan keimanan kepada Tuhan Yang Maha Esa, menstimulasi anak untuk dapat mempraktikan ibadah sesuai agama yang dianut dan menstimulasi anak dalam pembiasaan untuk berperilaku terpuji. 


\section{b. Apek Perkembangan Fisik Motorik}

Perkembangan fisik motorik merupakan salah satu bagian terpenting dalam perkembangan anak. Perkembangan fisik motorik harus distimulasi sejak usia dini karena berkaitan dengan keterampilan gerak yang akan memudahkan dan mempengaruhi keluwesan gerak setiap individu, baik gerak kasar yang melibatkan otot-otot besar maupun gerakan halus yang melibatkan koordinasi jari-jari tangan dengan mata. Fisik motorik terdiri dari 3 bagian, yaitu Motorik Kasar, Motorik Halus serta Kesehatan dan perilaku keselamatan.

Kemampuan fisik motorik yang baik akan memberikan rangsangan kepada anak dalam hal mencoba melakukan berbagai gerakan (baik gerakan kasar maupun gerakan halus), gerakan motorik yang dilakukan anak juga akan mempengaruhi kesehatan (bergerak membantu meningkatkan kesehatan anak), dan anak akan memiliki keterampilan dalam melakukan berbagai gerakan.

Kesehatan dan perilaku keselamatan yang terdiri dari tinggi badan, lingkar kepala sesuai usia serta kemampuan berperilaku hidup bersih, sehat, dan peduli terhadap keselamatannya. Guru menstimulasi terkait pengenalan dan pembiasaaan hidup bersih dan sehat dan mengupayakan keamanan anak dan lingkungan yang aman bagi pertumbuhan anak didik.

\section{c. Aspek Perkembangan Kognitif}

Proses kognitif berhubungan dengan tingat kecerdasan yang menandai seseorang dengan berbagai minat terutama sekali dittentukan kepada ide - ide dan belajar.

Dacholfany dan Hasanah (2018:77) menyimpulkan "kognitif adalah suatu proses berfikir, yaitu kemampuan individu untuk menghubungkan, menilai, dan mempertimbangkan suatu kejadian atau peristiwa".

Perkembangan kognitif merupakan perkembangan pada anak terkait kemampuan untuk menggunakan kekuatan berfikirnya. Lingkup pencapaian perkembangan kognitif terdapat 3 indikator yaitu : kemampuan berfikir logis, belajar dan pemecahan masal dan berfikir simbolik. Hubungan antara pencapaian perkembangan kognitif anak yang baik di masa dini dapat membuat anak bertahan untuk berjuang di masa depan.

\section{d. Aspek Perkembangan Bahasa}

Dacholfany dan Hasanah (2018:88) menyimpulkan perkembangan bahasa merupakan instrumen pokok bagi manusia dalam berpikir, memperoleh pengetahuan dan menghasilkan berbagai ilmu bahasa dalam kapasitasnya sebagai simbol-simbol konsepsi, memungkinkan manusia memperoleh semua konsepsi dalam pemikirannya secara simbolik. Aspek perkembangan bahasa merupakan salah satu aspek perkembangan anak yang diekspresikan melalui pemikiran anak usia dini dalam mengungkapkan kata-kata, memperoleh pengetahuan dan menghasilkan berbagai ilmu dalam kapasitasnya anak sebagai simbol-simbol konsep, yang menunjukkan meningkatnya kemampuan dan keativitas anak sesuai dengan tahap perkembangannya yang dipengaruhi oleh faktor biologis, lingkungan dan belajar.

\section{e. Aspek Sosial Emosional}

Perkembangan aspek sosial emosional anak usia dini dalam menyesuaikan diri untuk mengendalikan perasaan dan memahami keadaan emosi anak serta proses belajar pada anak tentang berinteraksi dengan orang lain disekitarnya yang sesuai dengan usianya. Dacholfany dan Hasanah (2018:91) Perkembangan sosial merupakan pencapaian kematangan dalam hubungan sosial. Proses belajar untuk menyesuaikan diri terhadap norma-norma, kelompok, moral, dan tradisi, meleburkan diri menjadi suatu kesatuan dan saling berkomunikasi dan bekerjasama. 
El Khuloqo (2015:25) Emosi diartikan sebagai suatu keadaan atau perasaan yang bergejolak dalam diri seseorang yang disadari dan diungkapkan melalui wajah atau tindakan, yang berfungsi sebagai inner adjustment (penyesuaian dari dalam) terhadap lingkungan untuk mencapai kesejahteraan dan keselamatan individu. Dari pendapat di atas, dapat disimpulkan bahwa perkembangan sosial emosional merupakan pencapaian kematangan dalam hubungan sosial emosional anak. Anak usia dini dapat saling berinteraksi, berkomunikasi dan bekerjasama dengan orang lain dengan perasaaan yang diungkapkan melalui wajah dan tindakan rasa senang, marah, jengkel dalam menghadapi lingkungan.

\section{f. Aspek Seni}

Perkembangan aspek seni anak usia dini adalah salah satu proses pencapaian dalam bidang seni melalui aktifitas seni seperti menggambar, bernyanyi, atau bermain musik. Pamadi (2012:247) menyatakan bahwa pendidikan seni adalah rasionalisasi, seni melalui keindahan. Keindahan adalah sesuatu yang dapat diukur menggunakan alat tertentu dan sesuai kebutuhan. Rasionalisasi keindahan dapat dilihat dari susunan, keseimbangan, maupun maknanya. Ketiganya merupakan prinsip dalam menciptakan karya seni.

Sumanto (2005:7) menyatakan tentang pengertian seni sebagai berikut: Seni adalah hasil atau proses kerja dan gagasan manusia melibatkan kemampuan trampil, kreatif, kepekaan indera, kepekaan hati dan pikir untuk menghasilkan suatu karya yang memiliki kesan keindahan, keselarasan, bernilai seni dan lainnya. Berdasarkan pendapat di atas aspek seni merupakan kemampuan mengeksplorasi dan mengeskpresikan diri berkaitan dengan estetika (keindahan) dalam sebuah karya seni. Aktifitas seni anak usia dini dapat meliputi kegiatan anak berimajinasi dengan gerakan musik, drama, dan beragam seni lainnya.

\section{METODE PENELITIAN}

Pendekatan yang penulis gunakan adalah pendekatan kualitatif yang artinya peneliti mengambil data kualitatif. Metode penelitian kualitatif yang digunakan adalah prosedur purposif. Prosedur purposir adalah salah satu strategi menentukan informan yang paling umum da dalam penelitian. Jenis penelitian sebagai peneilian deskriptif kualitatif, dimana peneliti sebagai instrumen kunci, teknik pengumpulan data dilakukan secara penggabungan dan analisis data bersifat induktif dan hasil penelitian kualitatif lebih menekankan makna daripaada generalisasi.

Pada penelitian kualitatif, peneliti memasuki situasi sosial tertentu yang dapat berupa lembaga pendidikan tertentu, melakukan observasi dan wawancara kepada orang-orang yang dipandang tahu tentang situasi sosial tersebut. Teori yang dikemukakan bersifat sementara dan akan berkermbang atau berubah setelah peneliti berada di lapangan.

\section{HASIL DAN PEMBAHASAN}

Analisis Pembelajaran dan Pencapaian Perkembangan Anak Usia Dini Pada Masa Pandemi Covid-19 di Lembaga PAUD Kota Metro Lampung

Berangkat dari fenomena yang terjadi di PAUD pada masa pandemi Covid-19, maka peneliti meneliti 2 (dua) lembaga sekolah yang dianggap mewakili dari kejadian tersebut, adapun hasil pembahasan dan temuan peneliti adalah:

\section{A. Pembelajaran PAUD}

Perencanaan pembelajaran merupakan salah satu cara yang dipergunakan oleh guru untuk mencapai tujuan pembelajaran yang akan ditetapkan. Seorang guru harus mampu memilih 
metode, materi dan media pembelajaran yang cocok untuk situasi dan kondisi lingkungan tempat belajar agar tercapai tujuan pembelajaran.

Berdasarkan hasil penelitian didapatkan informasi bahwa guru PAUD di Kota Metro Lampung pada masa pandemi Covid-19 melakukan pembelajaran melalui BDR (Belajar Dari Rumah) melalui metode luar jaringan (luring) dan dalam jaringan (daring) dengan memperhatikan unsur-unsur karakteristik pembelajaran, komponen pembelajaran dan prinsip pembelajaran.

\section{Karakteristik Pembelajaran}

Berdasarkan hasil wawancara, observasi dan dokumentasi dapat disimpulkan karakteristik anak antara lain: anak bersifat unik, masih berada dalam masa potensial atau golden age (masa keemasan anak), terkadang anak masih bersifat relatif spontan, cenderung ceroboh dan kurang perhitungan dalam mengambil keputusan bermain,anak bersifat aktif, energik, egosentris,memiliki rasa ingin tahu yang kuat, berjiwa petualang, dan memiliki imajinasi dan fantasi yang tinggi. Pada masa pandemi Covid-19, mau tidak mau, suka atau tidak, semua pihak mulai guru, orangtua, dan murid harus siap menjalani kehidupan baru. Didapatkan laporan penurunan stimulasi pengembangan karakter pada kemandirian, rasa percaya diri dan tanggungjawab.

Karakteristik pembelajaran anak usia dini pada hakikatnya adalah pembelajaran yang berorientasi bermain (belajar sambil bermain dan bermain sambil belajar), pembelajaran yang berorientasi perkembangan yang lebih banyak memberi kesempatan kepada anak untuk dapat belajar dengan cara-cara yang tepat. Pembelajaran pada anak usia dini pada dasarnya adalah penciptaan lingkungan atau pengkondisian dan pemberian perilaku atau pengalaman tertentu agar anak dapat berubah, dalam hal ini adalah tumbuh dan berkembang secara optimal sesuai dengan yang diharapkan.

\section{Komponen Pembelajaran}

Berdasarkan hasil wawancara, observasi dan dokumentasi ditemukan perencanaan pembelajaran dalam dokumen KTSP (Kurikulum Tingkat Satuan Pendidikan) pada lembaga di Kota Metro yang memuat tentang Komponen- komponen pembelajaran antara lain : tujuan, metode, materi, media atau alat dan bahan serta evaluasi penilaian perkembangan anak.

Perencanaan pembelajaran merupakan salah satu upaya yang dilakukan oleh guru agar anak didik dapat melaksanakan proses belajar dengan baik dan efektif. Dalam proses belajar tersebut terdapat komponen-komponen yang saling berhubungan satu sama lain. Komponenkomponen tersebut merupakan hal-hal yang menjadikan proses belajar tersebut berlangsung. Tanpa komponen pembelajaran maka tidak akan terjadi proses belajar yang efektif.

\section{Prinsip Pembelajaran}

Berdasarkan hasil wawancara, observasi dan dokumentasi ditemukan bahwa lembaga PAUD di Kota Metro telah menerapkan pembelajaran PAUD dengan memperhatikan prinsip prinsip pembelajaran anak usia dini antara lain :

1) Prinsip belajar melalui bermain, pemberian stimulasi rangsangan pembelajaran dilakukan dengan bermain meskipun dalam masa pandemi Covid-19,

2) Guru telah mengembangkan 6 aspek perkembangan sesuai tahapan usia anak yaitu 4-6 tahun,

3) Guru telah menstimulasi anak didik sesuai dengan kebutuhan dasar anak yaitu kebutuhan dalam hal kesehatan, pendidikan, pengasuhan, dan perlindungan, 
4) Guru berupaya menciptakan suasana yang bisa mendorong semangat belajar anak didik dengan pembelajaran yang aktif dan berpusat kepada anak dengan mendapatkan pendampingan dari orangtua,

5) Guru berupaya mendorong anak aktif mencari, menemukan, menentukan pilihan, mengemukakan pendapat dan melakukan kegiatan sendiri meskipun pembelajaran dilakukan di rumah,

6) Pembelajaran yang dilakukan oleh guru berorientasi pada pengembangan karakter anak didik. Pemberian tugas untuk mengembangkan kompetensi pengetahuan dan keterampilan disesuaikan dengan konsisi lingkungan tempat tinggal anak didik melalui kegiata pembiasaan bersama orangtua,

7) Guru berupaya memberikan stimulasi pengembangan kecakapan hidup yang dilakukan dengan pemberian tugas pembiasaan kemandirian

8) Bersama orangtua dan guru menciptakan lingkungan pembelajaran yang kondusif agar anak didik aman dan nyaman saat belajar,

9) Guru berupaya memberikan pembelajaran yang demokratis, mengembangkan rasa saling menghargai dengan orang lain,

10) Guru berupaya memanfaatkan media belajar yang ada di lingkungan tempat tinggal dan menggunakan media teknologi Informasi dan Komunikasi (TIK) seperti aplikasi zoom meeting dan whatsapp group.

Adapun prinsip-prinsip pembelajaran PAUD ini tertuang dalam Peraturan Menteri pendidikan dan Kebudayaan RI No. 146 Tahun 2014 tentang Kurikulum 2013 PAUD.

Dapat disimpulkan dari temuan diatas bahwa prinsip - prinsip pembelajaran PAUD ada 10 prinsip antara lain : 1) Belajar melalui bermain, 2) berorientasi pada perkembangan anak, 3) berorientasi pada kebutuhan anak, 4) berpusat pada anak, 5) pembelajaran aktif, 6) berorientasi pada pengembangan nilai karakter, 7) berorientasi pada pengembangan kecakapan hidup, 8) lingkungan yang kondusif 9) Berorietasi pada pembelajaran demokratis, dan 10) pemanfaatan media belajar dan sumber belajar.

\section{B. Pencapaian Perkembangan Anak}

Berdasarkan hasil wawancara, observasi dan dokumentasi peneliti di Lembaga PAUD Kota Metro Lampung, pembelajaran PAUD harus mengandung 6 (enam) aspek perkembangan anak, yaitu: aspek nilai agama dan moral, aspek fisik motorik, aspek kognitif, aspek bahasa, aspek sosial emosional dan aspek seni.

\section{Aspek Nilai Agama dan Moral}

Hasil penelitian mendapatkan informasi bahwa guru di TK Aisyiyah Iringmulyo menstimulasi anak didik pada aspek nilai agama dan moral sebelum pandemi Covid-19 dengan pembiasaan hafalan doa-doa, mengaji dan hadist, pembiasaan praktek sholat, dan adzan.

TK Aisyiyah Iringmulyo

Sebelum Pandemi

Covid-19
Pandemi
Covid-19
TK Cahaya Bangsa

Sebelum Pandemi

Covid-19
Pandemi

Covid-19 


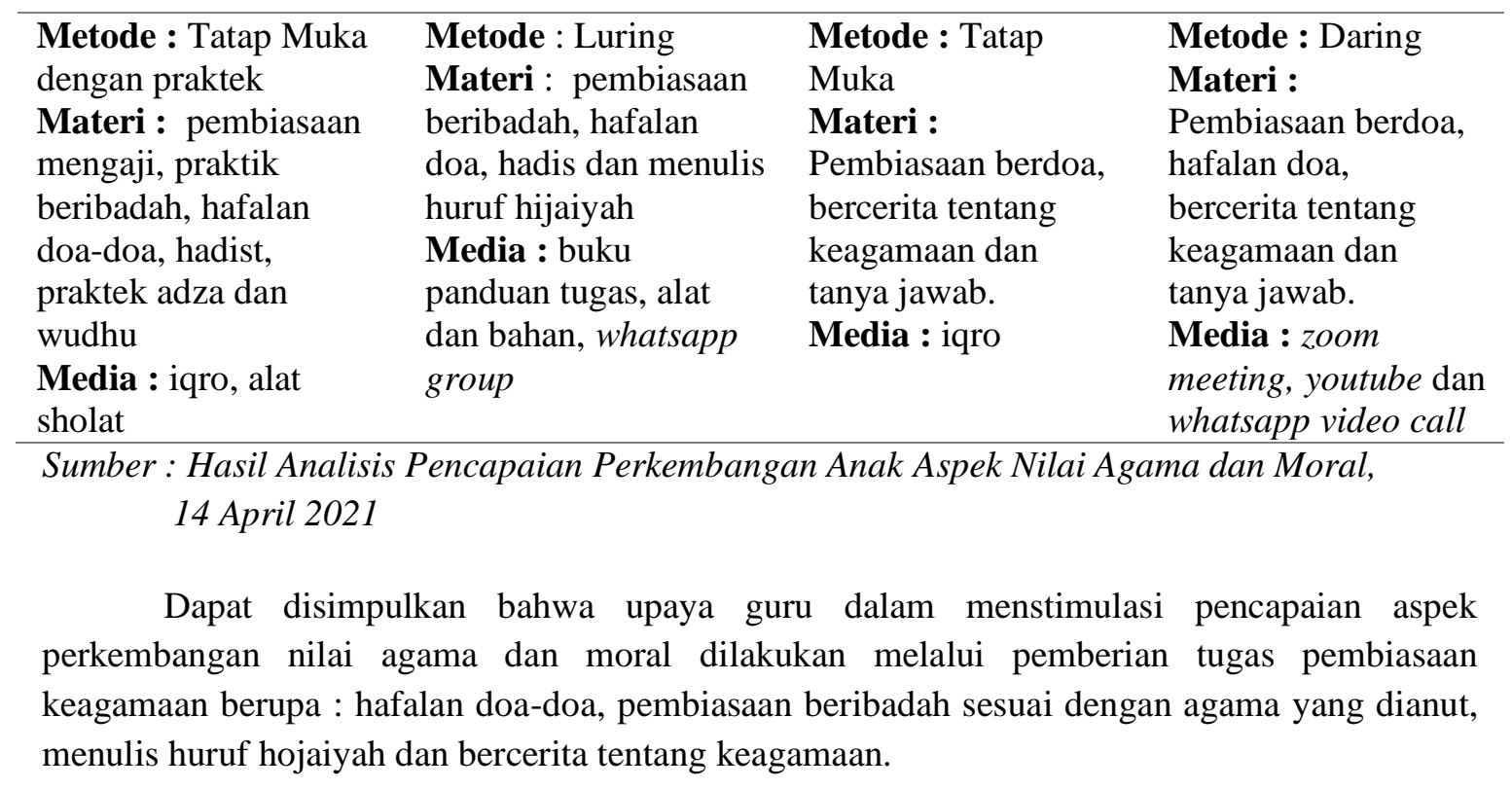

\section{Aspek Fisik Motorik}

Hasil penelitian dari TK Aisyiyah Iringmulyo berdasarkan wawancara, observasi dan dokumentasi di dapatkan bahwa sebelum pandemi Covid-19 guru dapat memantau aspek perkembang fisik motorik dengan berbagai kegiatan.

\section{TK Aisyiyah Iringmulyo}

Sebelum Pandemi

Covid-19

Pandemi
Covid-19

\section{TK Cahaya Bangsa}

$\begin{array}{cc}\text { Sebelum Pandemi } & \text { Pandemi } \\ \text { Covid-19 } & \text { Covid-19 }\end{array}$

\begin{tabular}{llll}
\hline Metode : Tatap Muka & Metode : Luring & Metode : Tatap & Metode : Daring dan \\
Materi : & Materi : & muka & Luring \\
Fisik Motorik Kasar : & Fisik Motorik Kasar & Materi : & Materi : \\
senam, gerak dan lagu, & : melempar, & Fisik motorik kasar : & menggambar, \\
bermain di halaman & menendang. & berjalan, berlari, & menulis, kolase, \\
sekolah & Melompat, & melompat, meluncur, menggunting dan \\
Fisik Motorik Halus : & merangkak, & memutar, melingkar, & menempel, gerak \\
menggambar, & bersepeda dan & melempar dan & dan lagu pembiasaan \\
mewarnai, menempel & melakukan gerakan & menangkap bola & pakai masker, cuci \\
kolase, menulis, & senam di rumah. & Fisik motorik halus : & tangan dan jaga jarak \\
menggunting & Fisik Motorik Halus & menggambar, & Media : buku \\
Kesehatan dan perilaku & : menggambar, & mewarnai, & panduan tugas, alat \\
hidup bersih : & menulis, kolase, & menempel, menulis & dan bahan, zoom \\
pembiasaan mencuci & menggunting dan & dan bermain puzzle & meeting, youtube \\
tangan sebelum makan, & menempel, & Kesehatan dan & dan whatsapp video \\
menggosok gigi, & pembiasaan senam, & perilaku keselamatan & call \\
memotong kuku dn & pakai masker dan & : gerak dan lagu & \\
membuang sampah & cuci tangan & menghindari orang & \\
Media : alat tulis & Media : buku & yang tidak dikenal & \\
sekolah & panduan tugas, alat & Media : buku & \\
& dan bahan, whatsapp & panduan tugas, alat & \\
& group & dan bahan sekolah & \\
\hline
\end{tabular}

Sumber : Hasil Analisis Pencapaian Perkembangan Anak Aspek Fisik Motorik, 14 April 2021 
Dapat disimpulkan bahwa aspek fisik motorik terdiri dari 3 bagian, yaitu motorik kasar, motorik halus serta kesehatan dan perilaku keselamatan. Motorik kasar merupakan gerakan yang dilakukan dengan melibatkan aktivitas otot besar dan anak mampu mengontrolnya. Ketrampilan motorik kasar ini mencakup kemampuan gerakan tubuh secara terkoordinasi, lentur, seimbang, lincah. Misal : berjalan, berlari, melompat, bersepeda, meluncur dan sebagainya. Motorik halus merupakan gerakan yang melibatkan aktivitas otot kecil dan gerakannya cenderung terbatas terutama aktivitas yang menggunakan jari-jari tangan dan jarijari kaki. Misalnya gerakan jari tangan anak dalam kegiatan menulis, meremas, menggamar dan mewarnai, merobel dan lain sebagainya. Kesehatan dan perilaku keselamatan yang terdiri dari tinggi badan, lingkar kepala sesuai usia serta kemampuan berperilaku hidup bersih, sehat, dan peduli terhadap keselamatannya.

\section{Aspek Kognitif}

Berdasarkan hasil penelitian di lembaga PAUD Kota Metro aspek kognitif terdapat 3 indikator fokus yaitu belajar dan pemecahan masalah, berfikir logis dan berfikir simbolik.

\begin{tabular}{|c|c|c|c|}
\hline \multicolumn{2}{|c|}{ TK Aisyiyah Iringmulyo } & \multicolumn{2}{|c|}{ TK Cahaya Bangsa } \\
\hline $\begin{array}{l}\text { Sebelum Pandemi } \\
\text { Covid-19 }\end{array}$ & $\begin{array}{l}\text { Pandemi } \\
\text { Covid-19 }\end{array}$ & $\begin{array}{c}\text { Sebelum Pandemi } \\
\text { Covid-19 }\end{array}$ & $\begin{array}{l}\text { Pandemi } \\
\text { Covid-19 }\end{array}$ \\
\hline $\begin{array}{l}\text { Metode : tatap muka } \\
\text { Materi : pemecahan } \\
\text { masalah, pemahaman } \\
\text { persamaan dan } \\
\text { perbedaan bentuk, } \\
\text { konsep, } \\
\text { mengklasifikasikan, } \\
\text { konsep sebab akibat } \\
\text { Media : alat permainan } \\
\text { edukatif, buku panduan }\end{array}$ & $\begin{array}{l}\text { Metode : Luring } \\
\text { Materi : pemecahan } \\
\text { masalah, persamaan } \\
\text { dan perbedaan, } \\
\text { pengenalan sebab } \\
\text { akibat } \\
\text { Media : buku tugas } \\
\text { panduan, alat dan } \\
\text { bahan, whatsapp } \\
\text { group }\end{array}$ & $\begin{array}{l}\text { Metode : tatap } \\
\text { muka } \\
\text { Materi : pemberian } \\
\text { dukungan untuk } \\
\text { berfikir logis, kritis, } \\
\text { dan kreatif dengan } \\
\text { pendekatan } \\
\text { saintifik } \\
\text { Media : alat } \\
\text { permainan edukatif, } \\
\text { buku panduan }\end{array}$ & $\begin{array}{l}\text { Metode : Daring dan } \\
\text { Luring } \\
\text { Materi : pemecahan } \\
\text { masalah, persamaan } \\
\text { dan perbedaan, } \\
\text { pengenalan sebab } \\
\text { akibat } \\
\text { Media : buku } \\
\text { panduan tugas, alat } \\
\text { dan bahan, zoom } \\
\text { meeting, youtube dan } \\
\text { whatsapp video call }\end{array}$ \\
\hline
\end{tabular}

Pada masa pandemi Covid-19 guru berupaya menstimulasi perkembangan anak melalui pemberian dukungan untuk menyelesaikan masalah. Guru dapat memberikan penghargaan kepada anak didik melalui jempol / tepuk tangan / apresiasi lain yang relevan. Indikator pembelajaran berfikir logis, kritis dan kreatif dilakukan anak didik melalui kegiatan pemahaman persamaan dan perbedaan gambar bentuk, konsep menghubungkan, mengklasifikasian berdasarkan bentuk, warna dan ukuran serta pemahaman konsep serbab akibat. Guru berupaya menstimulasi anak didik untuk berfikir logis melalui kegiatan kegiatan mengenal konsep bilangan dan huruf.

\section{Aspek Bahasa}

Didapatkan informasi dari hasil wawancara dan observasi bahwa fokus indikator pada aspek bahasa adalah memahami bahasa, mengungkapkan bahasa dan keaksaraan. 


\begin{tabular}{|c|c|c|c|}
\hline \multicolumn{2}{|c|}{ TK Aisyiyah Iringmulyo } & \multicolumn{2}{|c|}{ TK Cahaya Bangsa } \\
\hline $\begin{array}{l}\text { Sebelum Pandemi } \\
\text { Covid-19 }\end{array}$ & $\begin{array}{l}\text { Pandemi } \\
\text { Covid-19 }\end{array}$ & $\begin{array}{c}\text { Sebelum Pandemi } \\
\text { Covid-19 }\end{array}$ & $\begin{array}{l}\text { Pandemi } \\
\text { Covid-19 }\end{array}$ \\
\hline $\begin{array}{l}\text { Metode : Tatap muka } \\
\text { Materi : menyimak, } \\
\text { tanya jawab, bercerita, } \\
\text { dan menceritakan } \\
\text { kembali } \\
\text { Media : buku cerita } \\
\text { dan alat permainan } \\
\text { edukatif }\end{array}$ & $\begin{array}{l}\text { Metode : Luring } \\
\text { Materi : pra } \\
\text { menulis dan pra } \\
\text { membaca } \\
\text { Media : buku tugas } \\
\text { panduan, alat dan } \\
\text { bahan, whatsapp } \\
\text { group }\end{array}$ & $\begin{array}{l}\text { Metode : tatap muka } \\
\text { Materi : menyimak, } \\
\text { mengungkapkan } \\
\text { bahasa dengan } \\
\text { ekspresi, pra menulis } \\
\text { dan membaca } \\
\text { Media : buku } \\
\text { panduan tugas }\end{array}$ & $\begin{array}{l}\text { Metode : Daring dan } \\
\text { Luring } \\
\text { Materi : menyimak, } \\
\text { mengungkapkan bahasa } \\
\text { dengan ekspresi, pra } \\
\text { menulis dan membaca } \\
\text { Media : buku panduan } \\
\text { tugas, alat dan bahan, } \\
\text { zoom meeting dan } \\
\text { whatsapp video call, } \\
\text { qiuzziz }\end{array}$ \\
\hline
\end{tabular}

Sumber : Hasil Analisis Pencapaian Perkembangan Anak Aspek Bahasa, 14 April 2021

Guru pada TK Aisyiyah Iringmulyo sebelum pandemi Covid-19 melakukan kegiatan dengan berupaya memfasilitasi proses pembelajaran agar anak memahami bahas reseptif (menyimak), mengungkapkan bahasa melalui tanya jawab, bercerita atau menceritakan kembali yang anak didik ketahui. Guru berupaya memfasilitasi keterampilan anak untuk mengungkapkan bahasa dengan ekspresif melalui kegiatan membaca dan menulis yang dilakukan dengan pemberian tugas rumah. TK Cahaya Bangsa melakukan stimulasi pada aspek perkembangan bahasa dilakukan melalui dalam jaringan (daring) media zoom meeting, whatsapp videocall dan quizziz. Untuk kegiatan pra menulis dan pra membaca guru berupaya membuat bahan tugas yang akan dibagikan kepada peserta didik seminggu sekali.

\section{Aspek Sosial Emosional}

Di dapatkan informasi berdasarkan wawancara, observasi dan dokumentasi tentang upaya guru menstimulasi aspek perkembangan sosial emosional terdapat 3 fokus indikator yaitu kesadaran diri, rasa tanggungjawab diri sendiri dan orang lain serta perilaku prososial.

\section{TK Aisyiyah Iringmulyo}

\section{Sebelum Pandemi} Covid-19

Pandemi
Covid-19

Sebelum Pandemi Covid-19

Pandemi

Covid-19

$\begin{array}{llll}\text { Metode : tatap muka } & \text { Metode : Luring } & \text { Metode : tatap muka } & \text { Metode : Daring Luring } \\ \text { Materi : pembiasaan } & \text { Materi : bermain } & \text { Materi : pembiasaan } & \text { Materi : peduli di } \\ \text { mengantri, disiplin, } & \text { dengan saudara, } & \text { mengantri, } & \text { lingkungan tolong } \\ \text { bertanggungjawab } & \text { membantu orangtua } & \text { bergantian, } & \text { menolong dan } \\ \text { Media : alat } & \text { dirumah, } & \text { bertanggungajwab } & \text { bekerjasama } \\ \text { permainan edukatif } & \begin{array}{l}\text { Media : buku tugas } \\ \text { panduan, alat dan }\end{array} & \begin{array}{l}\text { Media : alat } \\ \text { permainan edukatif }\end{array} & \begin{array}{l}\text { Media : buku panduan } \\ \text { tugas, alat dan bahan, }\end{array} \\ & \text { bahan, whatsapp } & & \text { zoom meeting, youtube } \\ & \text { group } & & \text { dan whatsapp video call, } \\ & & & \text { quizziz }\end{array}$

Sumber : Hasil Analisis Pencapaian Perkembangan Anak Aspek Sosial Emosional, 14 April 2021

Hasil penelitian yang didapatkan dari TK Aisyiyah Iringmulyo menjelaskan bahwa upaya guru sebelum pandemi dalam menstimulasi aspek sosial emosional dengan indikator 
kesadaran diri atau anak didik mengendalikan dirinya melalui kegiatan pembiasaan mengantri, disiplin dan bertanggungjawab dalam melaksanakan perintah guru. Upaya guru di TK Cahaya Bangsa dalam pengendalian diri hampir sama sebelum terjadi pandemi Covid-19, guru membiasakan anak didik untuk terbiasa mnegantri saat cuci tangan dan bergantian saat menggunakan alat bermain. Pembiasaan untuk bertanggungjawab dalam membereskan peralatan makan dan alat main. Kegiatan interaksi bersama teman dapat terjadi di sekolah.

\section{Aspek Seni}

Berdasarkan hasil wawancara, observasi dan dokumentasi yang telah dilakukan oleh peneliti didapatkan informasi bahwa upaya yang telah dilakukan guru untuk ketercapaian aspek seni sebelum terjadi Covid-19 pada TK Aisyiyah Iringmulyo antara lain : mengajarkan anak untuk menikmati lagu atau suara, gerak dan lagu, mengenalkan kegiatan seni budaya kepada anak didik seperti kegiatan menari. Pada masa pandemi Covid-19 ini untuk indikator kegiatan seni mengalami penurunan. Guru tidak dapat melakukan pembelajaran kegiatan seni tari, mengenalkan pakaian adat dan lagu budaya Lampung.

\begin{tabular}{|c|c|c|c|}
\hline \multicolumn{2}{|c|}{ TK Aisyiyah Iringmulyo } & \multicolumn{2}{|c|}{ TK Cahaya Bangsa } \\
\hline $\begin{array}{l}\text { Sebelum Pandemi } \\
\text { Covid-19 }\end{array}$ & $\begin{array}{l}\text { Pandemi } \\
\text { Covid-19 }\end{array}$ & $\begin{array}{l}\text { Sebelum Pandemi } \\
\text { Covid-19 }\end{array}$ & $\begin{array}{l}\text { Pandemi } \\
\text { Covid-19 }\end{array}$ \\
\hline $\begin{array}{l}\text { Metode : tatap muka } \\
\text { Materi : } \\
\text { mendengarkan lagu } \\
\text { atau suara, gerak dan } \\
\text { lagu, menari } \\
\text { Media : tape musik }\end{array}$ & $\begin{array}{l}\text { Metode : luring } \\
\text { Materi : } \\
\text { mendengarkan lagu } \\
\text { Media : video dan } \\
\text { whatsapp group }\end{array}$ & $\begin{array}{l}\text { Metode : tatap muka } \\
\text { Materi : } \\
\text { mendengarkan lagu } \\
\text { dan pengenalan seni } \\
\text { budaya lampung, } \\
\text { menari } \\
\text { Media : buku } \\
\text { panduan, alat tulis } \\
\text { sekolah, tape musik, } \\
\text { video }\end{array}$ & $\begin{array}{l}\text { Metode : Luring dan } \\
\text { Daring } \\
\text { Materi : mendengarkan } \\
\text { lagu dan pengenalan seni } \\
\text { budaya lampung } \\
\text { Media : buku panduan } \\
\text { tugas, alat tulis sekolah, } \\
\text { zoom meeting, whatsapp } \\
\text { video call, youtube, } \\
\text { simple paint }\end{array}$ \\
\hline
\end{tabular}

Sumber : Hasil Analisis Pencapaian Perkembangan Anak Aspek Seni, 14 April 2021

Upaya guru dilakukan dengan ketercapaian seni melalui kegiatan zoom meeting. Guru berusaha tetap mengenalkan seni budaya kepada peserta didik melalui gambar dan gerakan tarian dasar sigeh pengunten.

\section{KESIMPULAN}

Berdasarkan tujuan penelitian disimpukan bahwa Metode pembelajaran yang digunakan guru adalah dengan metode luar jaringan (luring) dan dalam jaringan (daring) dapat meningkatkan pencaipaian pembelajaran PAUD di Kota Metro Lampung pada masa pandemi Covid-19.

\section{DAFTAR PUSTAKA}

Abin Syamsuddin Makmun. (2012). Psikologi Pendidikan Perangkat Sistem Pengajaran. Modul. Bandung: PT Remaja Rosdakarya. 
Achmad, W. (2020). Pendidikan Agama Islam Dalam Keluarga Sebagai Strategi Pendidikan Anak Usia Dini Saat Pandemi Covid-19. JCE (Journal of Childhood Education), 4(1), 71-83. https://doi.org/10.24036/108806

Ahmad Tanzeh. (2004). Metode Penelitian Praktis. PT Bina Ilmu. Jakarta pusat.

Ayuni, D., Marini, T., Fauziddin, M., \& Pahrul, Y. 2020. Kesiapan Guru TK Menghadapi Pembelajaran Daring Masa Pandemi Covid-19. Jurnal Obsesi: Jurnal Pendidikan Anak Usia Dini, 5(1), 414-421.

Daryanto. (2015). Pengelolaan Budaya dan Iklim Sekolah. Yogyakarta: Gava Media.

Djamarah, Syaiful Bahri dan Aswan Zain. (2002). Strategi Belajar Mengajar. Jakarta: Rineka Cipta.

Deliviana, E. (2017). Mempersiapkan Anak Masuk Sekolah Dasar. Jurnal Dinamika Pendidikan, 10(2), 119-133.

Diana Mutiah. (2010). Psikologi Bermain Anak Usia Dini. Jakarta: Kencana.

El-Khuluqo. (2015). Manajemen PAUD. Yogyakarta: Pustaka Pelajar

Gunawan, Suranti, N. M. Y., \& Fathoroni. (2020). Variations of Models and Learning Platforms for Prospective Teachers During the COVID-19 Pandemi Period. Indonesian Journal of Teacher Edukation, 1, 61-70.

Hildayani, Rini, dkk. (2014). Psikologi perkembangan anak. Jakarta

Hartati Sofia. (2005). Perkembangan Belajar Pada Anak Usia Dini. Jakarta: Departemen Pendidikan Nasional

Hamalik, O. (2006). Proses Belajar Mengajar. Bandung: PT. Remaja. Rosdakarya.

Komalasari, Kokom. (2010). Pembelajaran Kontekstual Konsep dan Aplikasi. Bandung: Refika Aditama.

Khaironi, M. (2018). Perkembangan anak usia dini. Jurnal Golden Age, 2(01), 01-12.

Kementerian Pendidikan dan Kebudayaan RI. (2020). Modul Penerapan penilaian perkembangan anak dalam kondisi khusus. Jakarta

Marsudi Saring. (2006). Permasalahan Dan Bimbingan di Taman Kanak-Kanak. FKIP UMS

M. Ichsan Dacholfany dan Uswatun Hasanah. (2018). Pendidikan Anak Usia Dini Menurut Konsep Islam, Jakarta, Amzah

Maspupah, U. (2018). Pengembangan Kurikulum di Lembaga Pendidikan Anak Usia Dini. Yinyang. Jurnal Studi Islam Gender Dan Anak, 13(1), 133-135.

MP Trianto. (2010). Mengembangkan Model Pembelajaran Tematik. Penerbit: PT. Prestasi Pustakaraya. Jakarta.

Montolalu, B.E.F, dkk. (2009). Bermain dan Permainan Anak. Jakarta : Universitas Terbuka

Novan Ardy Wiyani \& Barnawi. 2012. Format PAUD, Konsep, Karakteristik, \& Implementasi Anak Usia Dini. Jogjakarta. PT. AB Ruzz Media 
Parmadi, Hajar. (2012). Seni Keterampilan Anak. Universitas Terbuka. Jakarta

Pramana, C. (2020). Pembelajaran Pendidikan Anak Usia Dini (PAUD) Dimasa Pandemi Covid-19. Indonesian Journal of Early Childhood: Jurnal Dunia Anak Usia Dini, 2(2), $115-123$

Rohayani, F. (2020). Menjawab Problematika Yang Dihadapi Anak Usia Dini di Masa. Qawwam. Journal For Gender Mainstreaming, 14(1), 29-50. https://doi.org/10.20414/Qawwam.v14i1.2310

Sagala, Syaiful. (2009). Kemampuan Profesional Guru dan Tenaga Kependidikan. Bandung. Alfabeta.

Sugiyono. (2010). Metode Penelitian Kuantitatif Kualitatif dan RND. Bandung. Alfabeta.

Sumanto. (2005). Pengembangan Kreativitas Seni Rupa Anak TK. Jakarta: Departemen Pendidikan Nasional.

Sujiono, Yuliani Nurani. (2010). Konsep Dasar Pendidikan Anak Usia Dini. Jakarta: Indeks.

Wulandari, H., \& Purwanta, E. .(2020). Pencapaian Perkembangan Anak Usia Dini di Taman Kanak-kanak selama Pembelajaran Daring di Masa Pandemi Covid-19. Jurnal Obsesi: Jurnal Pendidikan Anak Usia Dini. 5(1), 452-462. 